\title{
Implications of free Shiga toxin-converting bacteriophages occurring outside bacteria for the evolution and the detection of Shiga toxin-producing Escherichia coli
}

\author{
Alexandre Martínez-Castillo and Maite Muniesa * \\ Department of Microbiology, Faculty of Biology, University of Barcelona, Barcelona, Spain
}

Edited by:

Eelco Franz, Centre for Infectious

Disease Control, Netherlands

\section{Reviewed by:}

Eelco Franz, Centre for Infectious Disease Control, Netherlands

Stefano Morabito, Istituto Superiore

di Sanità, Italy

\section{*Correspondence:}

Maite Muniesa, Department of Microbiology, Faculty of Biology,

University of Barcelona, Av. Diagonal 643, 08028 Barcelona, Spain

e-mail:mmuniesa@ub.edu
In this review we highlight recent work that has increased our understanding of the distribution of Shiga toxin-converting phages that can be detected as free phage particles, independently of Shiga toxin-producing bacteria (STEC). Stx phages are a quite diverse group of temperate phages that can be found in their prophage state inserted within the STEC chromosome, but can also be found as phages released from the cell after activation of their lytic cycle. They have been detected in extraintestinal environments such as water polluted with feces from humans or animals, food samples or even in stool samples of healthy individuals. The high persistence of phages to several inactivation conditions makes them suitable candidates for the successful mobilization of stx genes, possibly resulting in the genes reaching a new bacterial genomic background by means of transduction, where ultimately they may be expressed, leading to Stx production. Besides the obvious fact that Stx phages circulating between bacteria can be, and probably are, involved in the emergence of new STEC strains, we review here other possible ways in which free Stx phages could interfere with the detection of STEC in a given sample by current laboratory methods and how to avoid such interference.

Keywords: bacteriophages, Shiga toxin, STEC, environment, transduction
Shiga toxin-producing Escherichia coli (STEC) are important food-borne pathogens and represent a challenge for the scientific community. Effort has been devoted to developing methods for its isolation, detection and identification, to guarantee the quality of products and the health of consumers. Many studies have aimed at gaining an understanding of the mobility of the important gallery of virulence factors that compose the virulome of the E. coli pathogenic strains. The mobility of these factors among strains is a key factor for the genotypic and phenotypic variability of this bacterium, and hinders the process of determining what should be considered a true pathogen and how to detect it effectively (Erickson and Doyle, 2007; Karch et al., 2012; Melton-Celsa et al., 2012).

Thus, the methods for $E$. coli detection have focused on those factors that are clearly related with virulence and, particularly, those that are closely related with high incidence and severity of human infections. Among these factors, the Shiga toxin (Stx) is considered one of the most significant and, if not the only one determining pathogenicity, the one that leads to the most undesirable complications of the infection, such as HUS (Tarr et al., 2005).

Stx is a good example of a mobile virulence factor, since the genes encoding for this toxin are located in the genome of temperate bacteriophages (Newland et al., 1985; Huang et al., 1987; O'Brien et al., 1989). Many phages simply multiply by infecting bacteria, killing the host by lysis and releasing new phages. Temperate phages, however, adopt a benign relationship with their hosts, called lysogeny, which allows an attachment of phage
DNA to a bacterial chromosome. For Stx phages, once a phage integrates its genome within the bacterial genome, the bacteria acquires the stx gene and with it the capacity to express the toxin; thereby becoming a STEC. Temperate phages can revert from the lysogenic state by entering the lytic cycle, mostly due to environmental conditions or exogenous factors. The lytic pathway starts by generating multiple copies of its genome, causing an increase in the Stx produced by the cell during the process (Neely and Friedman, 1998; Wagner et al., 2001; Tyler et al., 2004). By the expression of the phage genome, new phage capsids are generated, assembled with the phage DNA and, once formed, phage particles are released from the cell by lysis. Once released, phage particles remain free outside the bacterial cell, and here is where our story starts.

The major question we address is: what happens to phages outside the cell and to what extent does their occurrence as free particles play a role in the evolution of new STEC strains?

Phages are rather simple particles and Stx phages are no exception. Their persistence outside the cell is guaranteed by their ability to circumvent natural and artificial inactivation processes (as reviewed in the next section), many of which would inactivate their bacterial host. It is the fact that the life cycle of phages switches to the lytic state that allows phages to be released once the cell has been threatened by factors that activate its SOS response (Muhldorfer et al., 1996; Kimmitt et al., 2000; Köhler et al., 2000; Yamamoto et al., 2003; Aertsen et al., 2005; Toshima et al., 2007; Pacheco and Sperandio, 2009). 


\section{Stx PHAGES IN FECALLY POLLUTED WATERS}

Several reports have shown the occurrence of free Stx phages in water environments with fecal pollution or directly on homogenates of fecal samples (Table 1). Most studies have only focused on the detection of Stx phages in general or Stx 2 phages in particular, and only a few have evaluated Stx1 phages (Dumke et al., 2006; Yan et al., 2011; Rooks et al., 2012). Those studies show a clear predominance of Stx 2 phages over Stx1 phages and, despite the fact that there is still a lack of information on the abundance of Stx1 phages in the environment, the results correlate with reported data on the predominance of stx 2 phages over Stxl phages in lysates induced from environmental $E$. coli isolates (Muniesa et al., 2004a; Garcia-Aljaro et al., 2009; Yan et al., 2011).

Regardless of the type of toxin variant, the high occurrence of free Stx phages detected suggests that Stx phages could do more than provide intestinal bacteria with a new genetic character. Although a certain level of human fecal contamination is always observed in environments where free Stx phages have been detected (Muniesa and Jofre, 1998; Tanji et al., 2003; Muniesa et al., 2004b; Dumke et al., 2006; Imamovic et al., 2010; Rooks et al., 2010, 2012) (Table 1), there is no total correlation between Stx phage occurrence and fecal pollution, as shown by comparison with fecal indicators (Dumke et al., 2006; Imamovic et al., 2010). This lack of correlation suggests that the fecal origin is the main but not necessarily the sole source of Stx phages. Accordingly, the description of Stx2-positive extraintestinal E. coli strains (Wester et al., 2013) supports the suspicion that stx is not restricted to a fecal origin. Stx phages are not limited to waters containing human contamination and they have also been found to be highly prevalent when analyzing wastewater from animals (Imamovic et al., 2010; Yan et al., 2011). Water with lower levels of fecal pollution, such as river water, also shows the presence of Stx phages (Muniesa et al., 1999; Dumke et al., 2006).

Table 1 | Occurrence and abundance of free Stx bacteriophages in diverse environments.

\begin{tabular}{|c|c|c|c|c|c|c|}
\hline \multirow[t]{2}{*}{ Sample } & \multirow[t]{2}{*}{ Country } & \multicolumn{3}{|c|}{ Detection of Stx phages } & \multirow[t]{2}{*}{ Detection method } & \multirow[t]{2}{*}{ References } \\
\hline & & Stx1 phages & Stx2 phages & Abundance & & \\
\hline Human wastewater & Spain & - & Positive (I) & 10 PFU.ml $\left.\right|^{-1}$ & $M P N+P C R$ & Muniesa and Jofre, 1998 \\
\hline Human wastewater & $\begin{array}{l}\text { Germany, } \\
\text { Austria, } \\
\text { France } \\
\text { Ireland } \\
\text { South Africa } \\
\text { New } \\
\text { Zaeland }\end{array}$ & - & $\begin{array}{l}\text { Positive } \\
\text { Positive } \\
\text { Positive } \\
\text { Positive } \\
\text { Positive } \\
\text { Positive }\end{array}$ & $\begin{array}{l}\geq 1 \text { PFU.ml } \mathrm{ml}^{-1} \\
>0.1 \text { PFU.ml } \mathrm{ml}^{-1} \\
\geq 10 \text { PFU.ml } \mathrm{ml}^{-1} \\
\geq 10 \text { PFU.ml } \mathrm{ml}^{-1} \\
\geq 10 \text { PFU.ml } \mathrm{ml}^{-1} \\
\geq 10 \text { PFU.ml } \mathrm{ml}^{-1}\end{array}$ & PCR & Muniesa and Jofre, 2000 \\
\hline Human wastewater & Japan & - & Positive (I) & - & PCR & Tanji et al., 2003 \\
\hline Human wastewater & Spain & - & Positive (I) & $4.24 \log _{10}$ PFU.ml $\mathrm{ml}^{-1}$ & Plaque count+PCR & Muniesa et al., 2004b \\
\hline Cattle wastewater & Spain & - & Positive (I) & $4.45 \log _{10}$ PFU.ml ${ }^{-1}$ & Plaque count+PCR & Muniesa et al., 2004b \\
\hline Human wastewater & Germany & Positive (I) & Positive (I) & $\begin{array}{l}\text { 0.34 PFU.ml-1 } \mathrm{stx}_{1} \\
\text { 3.4 PFU.ml }{ }^{-1} \mathrm{stx}_{2}\end{array}$ & $\begin{array}{l}\text { Plaque count } \\
\text { PCR estimation }\end{array}$ & Dumke et al., 2006 \\
\hline $\begin{array}{l}\text { Human treated } \\
\text { waste water }\end{array}$ & Germany & Negative & Positive (I) & - & Plaque count+PCR & Dumke et al., 2006 \\
\hline River water & Germany & Positive (I) & Positive (I) & - & Plaque count+PCR & Dumke et al., 2006 \\
\hline Human wastewater & UK & Negative & Positive (I) & $9.41 \log _{10}$ PFU.ml $\mathrm{ml}^{-1}$ & Plaque count+PCR & Rooks et al., 2010 \\
\hline Human wastewater & UK & Negative & Positive & $2.39 \log _{10} \mathrm{GC} . \mathrm{ml}^{-1}$ & qPCR & Rooks et al., 2010 \\
\hline Human wastewater & Spain & - & Positive & $1.37 \log _{10} \mathrm{GC} \cdot \mathrm{ml}^{-1}$ & qPCR & Imamovic et al., 2010 \\
\hline Cattle wastewater & Spain & - & Positive & $2.77 \log _{10} \mathrm{GC} \cdot \mathrm{ml}^{-1}$ & qPCR & Imamovic et al., 2010 \\
\hline Pig wastewater & Spain & - & Positive & $4.59 \log _{10} \mathrm{GC} \cdot \mathrm{ml}^{-1}$ & qPCR & Imamovic et al., 2010 \\
\hline Poultry wastewater & Spain & - & Positive & $1.11 \log _{10} \mathrm{GC} \cdot \mathrm{ml}^{-1}$ & qPCR & Imamovic et al., 2010 \\
\hline Cattle feces & Spain & - & Positive & $2.32 \log _{10} \mathrm{GC} . \mathrm{g}^{-1}$ & qPCR & Imamovic et al., 2010 \\
\hline Beef & Spain & - & Positive (I) & $4.10 \log _{10}$ GC. $g^{-1}$ & qPCR & $\begin{array}{l}\text { Imamovic and Muniesa, } \\
2011\end{array}$ \\
\hline Salad & Spain & - & Positive (I) & $3.36 \log _{10} \mathrm{GC} . \mathrm{g}^{-1}$ & qPCR & $\begin{array}{l}\text { Imamovic and Muniesa, } \\
2011\end{array}$ \\
\hline Swine feces & China & Positive (I) & Positive (I) & - & Plaque count+PCR & Yan et al., 2011 \\
\hline Wastewater & UK & - & Positive (I) & - & Lysogen isolation & Rooks et al., 2012 \\
\hline Human feces & Spain & - & Positive (I) & $4.41 \log _{10} \mathrm{GC} . \mathrm{g}^{-1}$ & qPCR & $\begin{array}{l}\text { Martinez-Castillo et al., } \\
2013\end{array}$ \\
\hline
\end{tabular}

GC, gene copy; PFU, plaque forming unit; MPN, most probable number. (I) those studies reporting infectious Stx phages. 


\section{Stx PHAGES IN FECES}

If fecally polluted waters present Stx phages, and assuming that Stx phages could have been generated in the intestinal gut, the question that remains to be answered is whether the phages are released into wastewaters by induction from STEC strains present in these environments, or whether free Stx phages are directly excreted through feces. Recent reports indicate that free infectious (those able to infect and propagate in a host strain), Stx2 phages are present in $62 \%$ of human feces (Martinez-Castillo et al., 2013). Sequencing of the PCR amplimers suggested that subtypes $s t x_{2 \mathrm{a}}, s t x_{2 \mathrm{c}}$, and $s t x_{2 \mathrm{~d}}$ were the most frequently detected (Martinez-Castillo et al., 2013). From the positive samples, 90\% showed infectious Stx phages. Two facts are to be highlighted from that study: there is not a high incidence of STEC in the area of this study; and the stool samples were taken from healthy individuals without reported gastrointestinal symptoms, and that STEC were not detected in or isolated from these samples.

\section{Stx PHAGES IN FOOD}

Assuming that Stx phages are excreted in feces, they must have been ingested, either as free phages or as STEC bacteria that were later induced, once in the intestinal tract. If they are ingested as free phages, then they must be present in food or drinking water, assuming that these are free of significant levels of bacteria. The occurrence of infectious Stx2 phages in commercial samples of beef and salad (Imamovic and Muniesa, 2011), that were acceptable for process hygiene microbiological criteria under EU regulation (Anonymous, 2005), highlights the gap that exists in legislation regarding the presence of phages in food samples.

The fact that phages detected in food were infectious is interesting, considering the likelihood of transduction in food matrices at different $\mathrm{pH}$ and temperatures (Imamovic et al., 2009) as well as under dairy processing conditions (Picozzi et al., 2012). This fact is of special relevance considering the observations that many food-processing conditions, such as thermal treatment, high hydrostatic pressures, or UV or other irradiation (Yamamoto et al., 2003; Aertsen et al., 2005; Yue et al., 2012), and the addition of certain compounds during the food production, such as chelating agents (Imamovic and Muniesa, 2011), salt (Harris et al., 2012) or antimicrobials (Kimmitt et al., 2000), not only fail to inactive of the Stx phages, but can enhance Stx phage induction from their STEC hosts.

\section{PERSISTENCE OF Stx PHAGES}

Generally speaking, phages could persist in different environments or under disinfection processes or inactivation conditions (Dee and Fogleman, 1992; Durán et al., 2002; Jofre, 2007; Lee and Sobsey, 2011). In habitats in which the host bacteria are alien, as fecal bacteria are in the environment, it is likely that phages persist much better than the bacteria (Ogunseitan et al., 1990; Muniesa et al., 1999; Durán et al., 2002). Because of their structural characteristics, their persistence in the environment is high, and these survival capabilities make bacteriophages especially suited for movement and gene transfer between different biomes.

Certain morphologies can be considered more persistent than others, tailed phages being the ones showing higher persistence
(Muniesa et al., 1999; Prigent et al., 2005; Lin et al., 2010). Notably, these are the most abundant in different water environments (Prigent et al., 2005; Lin et al., 2010). Stx phages mostly belong to the Siphoviridae and Podoviridae morphological types (Rietra et al., 1989; Muniesa et al., 2004a,b; Beutin et al., 2012), showing similar persistence to that of other groups of phages (Muniesa et al., 1999; Dumke et al., 2006; AlluéGuardia et al., 2014) and higher persistence than STEC (Muniesa et al., 1999; Mauro and Koudelka, 2011; Rode et al., 2011; AlluéGuardia et al., 2014). Stx phages have been shown to be very stable under food-processing conditions (Yamamoto et al., 2003; Aertsen et al., 2005; Imamovic et al., 2009; Rode et al., 2011; Harris et al., 2012; Yue et al., 2012; Langsrud et al., 2013; AlluéGuardia et al., 2014). In contrast, they do not seem to persist so well under strict treatments such as that linked to the compost model (Johannessen et al., 2005). Nevertheless, their persistence, as for other phages, enhances their mobility between the different environments (feces-food-water) (Mauro and Koudeljka).

Another question is whether the STEC hosts could survive the time necessary to allow phage release before being killed by the treatment applied, or if phages, once released, could remain infectious. Infectivity of Stx phages has been demonstrated after exposure to certain conditions, and some Stx phages remain able to generate lysogens, hence to transduce stx (Muniesa and Jofre, 1998; Imamovic et al., 2009; Rode et al., 2011; Yue et al., 2012). The capacity to remain infectious after being subjected to a given condition will determine the chances of stx transduction, the real threat in the generation of new STEC strains.

\section{INTERFERENCE OF Stx PHAGES IN STEC DETECTION}

The identification of STEC by culture methods in food or clinical samples is advisable to confirm the presence of the pathogen and to further characterize it. However, sometimes strain recovery is not possible because of the low number of STEC cells in a specific sample, the fact that cells could be stressed or in a non-culturable state, or because of the interference of accompanying microbiota, particularly other E. coli strains that could confound the detection of the pathogen even when using a specific culture medium. Culture detection of STEC is, in addition, a time-consuming method that hinders early diagnosis of STEC.

Early diagnosis of STEC infection in humans is nevertheless critical for the treatment of the disease, particularly because of the contraindication for treating STEC using antimicrobial agents, and the intense supportive care needed if renal failure occurs (Wong et al., 2000). The need for fast detection and the associated difficulties of STEC isolation from stools in patients treated with antibiotics makes the use of fast and robust molecular methods advisable for STEC detection.

Current laboratory methods for STEC detection, some standardized and approved by national legislation, include PCR-based techniques: either end-point or real-time PCR (Paton and Paton, 2003; Perelle et al., 2004; Gould et al., 2009; Kagkli et al., 2011; Bibbal et al., 2014). Recently, ISO 13136:2012 (Anonymous, 2012), which uses real-time PCR as the reference technology for 
the detection of the virulence and serogroup-associated genes, has been included in the amended EU regulation for microbiological criteria for sprouts and the sampling rules for poultry carcasses and fresh poultry meat (European commission regulation No. 209/2013). With the same aim in mind, molecular techniques, many based on the information obtained by the use of next-generation sequencing (NGS) methods, are being explored and advised (Baquero and Tobes, 2013; Underwood et al., 2013).

As indicated above, the genomic plasticity of STEC represents a challenge for discriminating pathogenic strains from other nonpathogenic E. coli strains present in a given sample. Thus, PCRbased molecular methods are mainly focused on genes related with virulence and on genes that identify a specific serotype, such as $r f b$ genes encoding different $O$ antigens (Maurer et al., 1999). Identification of the serotype could be useful for epidemiological purposes and, generally, virulent strains belong to one of the serogroups that account for the non-O157 serotype, including O26, O45, O103, O111, O121, and O145, plus O157:H7 (USDA FSIS, 2012). Lessons learnt from the last outbreak in Germany (Karch et al., 2012) forced researchers to include O104:H4 on the list, and showed that identification of serotype, albeit very useful when treating known pathotypes or for epidemiological purposes, is of limited value for dealing with a newly emerging strain. If STEC isolation is not possible, identifying virulence genes, alone or preferably in combination, appears to be the best approach for assessing the presence of STEC in a sample.

However, when dealing with molecular methods applied to a sample, the presence of free Stx phages, and also other phages that could harbor virulence genes, represents a challenge for the use of PCR-based and NGS methodologies. Moreover, when the protocols include a previous step of selective enrichment of the target bacteria, this step could also maintain or even propagate bacteriophages. This is even more significant if we assume that the methods used for bacterial DNA extraction in these complex matrices will also extract phage DNA (Paton and Paton, 2003; Monday et al., 2007; Grys et al., 2009; ISO 13136:2012). Therefore, any virulence genes present in phage DNA, notably $s t x$ genes, but also other virulence genes reported in prophages (e.g., $c d t$, cif, etc.) (Asakura et al., 2007; Loukiadis et al., 2008) would generate amplimers (PCR) or reads (NGS) that will be interpreted as belonging to STEC, while it could be that they originated in phages. Since in STEC these genes belong to prophages, and therefore are flanked by phage sequences, there is no easy way to distinguish whether the target detected is a bacteria or a phage. If it is a phage, the threat of virulence in humans must be discussed, but it obviously has reduced potential for virulence and would not be enough to raise the alarm.

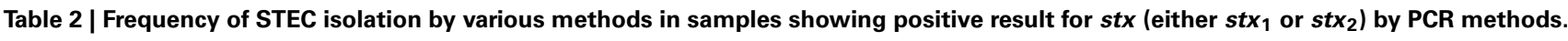

\begin{tabular}{|c|c|c|c|c|}
\hline & $\begin{array}{c}\text { No of stx- } \\
\text { positive } \\
\text { samples by PCR }\end{array}$ & $\begin{array}{l}\text { No of stx-positive } \\
\text { samples by PCR with } \\
\text { STEC isolation }\end{array}$ & $\begin{array}{l}\text { Percentage of PCR stx- } \\
\text { positive samples with } \\
\text { STEC isolation (\%) }\end{array}$ & References \\
\hline Humans stools (asymptomatic) & 196 & 47 & 24 & Stephan et al., 2000 \\
\hline Human stools (volunteers) & 21 & 1 & 4.8 & Urdahl et al., 2012 \\
\hline Children stools (hospital) & 21 & 5 & 24 & Vallières et al., 2013 \\
\hline Children stools (hospital) & 19 & 10 & 52.6 & Pradel et al., 2000 \\
\hline Cattle feces & 145 & 80 & 55.2 & Fremaux et al., 2006 \\
\hline Cattle feces & 154 & 67 & 43.5 & Rogerie et al., 2001 \\
\hline Cattle feces & 417 & 18 & 4.3 & Hofer et al., 2012 \\
\hline Bovine carcasses & 91 & 16 & 17.6 & Rogerie et al., 2001 \\
\hline Cattle environment & 179 & 38 & 21.2 & Fremaux et al., 2006 \\
\hline Beef meat & 47 & 16 & 34.0 & Pradel et al., 2000 \\
\hline Dairy buffalo (feces and milk) & 56 & 20 & 35.7 & Beraldo et al., 2014 \\
\hline Milk (bulk) & 32 & 1 & 3.1 & Trevisani et al., 2014 \\
\hline Milk (filters) & 68 & 7 & 10.3 & Trevisani et al., 2014 \\
\hline Cheese & 60 & 5 & 8.3 & Pradel et al., 2000 \\
\hline Healthy pigs feces & 255 & 62 & 24.3 & Meng et al., 2014 \\
\hline Swine feces & 484 & 196 & 40.5 & Fratamico et al., 2004 \\
\hline Meat products & 36 & 8 & 22.2 & Díaz-Sánchez et al., 2012 \\
\hline
\end{tabular}

\footnotetext{
${ }^{*}$ Calculated from the $\%$ of positive samples.
} 
In addition to those well-characterized phages encoding virulence genes in STEC, many lytic phages could mobilize bacterial genes by generalized transduction. In transduction, after random packaging of bacterial DNA fragments, the genetic material can be mobilized by a phage from a donor bacterium and inserted into a recipient bacterium when it becomes infected by the phage particle. Despite a lack of clear evidence of generalized transduction relating to STEC, any bacterial gene can be mobilized via generalized transduction, including chromosome fragments, though plasmids, transposons and insertion elements, and examples in enterobacteria can also be found (Mann and Slauch, 1997; Schmieger and Schicklmaier, 1999).

Generalized transduction is considered a rare event (Bushman, 2002); however, many approaches for STEC detection based on genomic techniques envisage preliminary steps for the selective or non-selective enrichment of the target microorganism (Hussein and Bollinger, 2008). Enrichment to propagate bacteria can cause the propagation of any sort of phages present in a sample too, a fact that, firstly, would cause a bias in the population of enriched bacteria (Muniesa et al., 2005), and secondly, by increasing the number of phages, would also theoretically cause an increase in the frequency of generalized transduction. As an example to illustrate this point, the protocols for P1 generalized transduction include a propagation step between the donor and the phage to increase the number of generalized transducing particles (Thomason et al., 2007).

Since Shiga toxin is the main virulence threat in STEC, there are many examples of stx positive PCR results from samples showing negative detection of culturable STEC. The percentage of samples showing STEC isolates among PCR stx-positive samples (either stools of food samples) is in many reports no higher than $50 \%$ (Table 2). In clinical stools samples this could be attributable to previous treatment with antimicrobial agents or to a disease being diagnosed late in its course. In food samples it could also be attributable to the presence of non-culturable microorganisms or the presence of bacteria in very low numbers. However, considering the presence of phages as described above, their role in these positive PCR detections or their involvement in sequences generated by NGS cannot be excluded.

\section{AVOIDING PHAGE INTERFERENCE}

The issue that arises is how to avoid phage interference. In theory, several methods could be applied to eliminate phages from the equation. These are mostly based on dismissing the phage population from the sample without interfering with the bacterial population and avoiding complicated steps in the methodology. Some protocols use a centrifugation step after the enrichment culture, and only the pellet containing bacteria is used for DNA extraction (Feng et al., 2011). This method would reduce the number of phages present in the supernatant of the enrichment; though to what extent, has not been tested. Still, phages present in the original samples would have propagated and would still be present in the bacterial pellet.

Filtration has also been proposed to separate phages from the sample and has been widely used to purify phage stocks or phages from a sample before counting (Brock, 1983; EPA, 2000). Microfiltration is mostly applied to retain viruses using the filter and clarify the sample (Van Reis and Zydney, 2001; Saxena et al., 2008), while here the aim is to eliminate phages by passing them through the filter but retaining the bacteria. The selection of the most efficient membrane, in terms of pore size and chemical structure, would be critical with this purpose in mind. The use of 0.22 or $0.45 \mu \mathrm{m}$ low protein binding membranes that do not retain phages would be advisable. Among these, polyvinylidene fluoride (PVDF), polyethersulfone (PES) or cellulose ester membranes saturated with beef extract have been proposed (Anonymous, 2000; EPA, 2000; Papageorgiou et al., 2000; Mocé-Llivina et al., 2003), and PVDF membranes have been shown to reduce by $2-3 \log _{10}$ the phages present in a bacterial enrichment culture (Muniesa et al., 2005). Complete elimination of all phages present in the samples will probably not be accomplished only by adding a single filtration step, but optimization of this approach would reduce the phage population enough to avoid interference in the molecular detection methods without adding complicated steps to the already-established protocols and without reducing the bacterial population. However, it must be borne in mind that filtration would turn out to be more useful when treating aqueous samples or clear homogenates of solid samples and with a variable efficiency depending on the complexity of the matrix, with lower recoveries expected when it is applied to solid or mixed samples that could clog the membranes.

\section{ACKNOWLEDGMENTS}

This study was supported by the Spanish Ministry of Education and Science (AGL2012-30880) and the Generalitat de Catalunya (2009SGR1043) and by the Spanish Reference Network of Biotechnology (XeRBa). Alex Martínez-Castillo has a grant from the Spanish Ministry.

\section{REFERENCES}

Aertsen, A., Faster, D., and Michiels, C. W. (2005). Induction of Shiga toxinconverting prophage in Escherichia coli by high hydrostatic pressure. Appl. Environ. Microbiol. 71, 1155-1162. doi: 10.1128/AEM.71.3.1155-1162.2005

Allué-Guardia, A., Martínez-Castillo, A., and Muniesa, M. (2014). Persistence of infectious Stx bacteriophages after disinfection treatments. Appl. Environ. Microbiol. 80, 2142-2149. doi: 10.1128/AEM.04006-13

Anonymous. (2000). ISO 10705-2: Water Quality. Detection and Enumeration of Bacteriophages -Part 2: Enumeration of Somatic Coliphages. Geneva: International Organisation for Standardisation.

Anonymous. (2005). Commission Regulation (EC) No 2073/2005 of 15 November 2005 on microbiological criteria for foodstuffs. Official J. Eur. Commun. $338,11-25$.

Anonymous. (2012). ISO 13136:2012. Microbiology of Food and Animal Feed-Realtime Polymerase Chain Reaction (PCR)-Based Method for the Detection of Foodborne Pathogens - Horizontal Method for the Detection of Shiga Toxin-producing Escherichia coli (STEC) and the Determination of O157, O111, O26, O103 and O145 Serogroups. Geneva: International Organisation for Standardisation.

Asakura, M. A., Hinenoya, M. S., Alam, K., Shima, S. H., Zahid, L., Shi, N., et al. (2007). An inducible lambdoid prophage encoding cytolethal distending toxin (Cdt-I) and a type III effector protein in enteropathogenic Escherichia coli. Proc. Natl. Acad. Sci. U.S.A. 104, 14483-14488. doi: 10.1073/pnas.0706695104

Baquero, F., and Tobes, R. (2013). Bloody coli: a gene cocktail in Escherichia coli O104:H4. MBio 4:e0066-13. doi: 10.1128/mBio.00066-13

Beraldo, L. G., Borges, C. A., Maluta, R. P., Cardozo, M. V., Rigobelo, E. C., and de Ávila, F. A. (2014). Detection of Shiga toxigenic (STEC) and enteropathogenic (EPEC) Escherichia coli in dairy buffalo. Vet. Microbiol. 170, 162-166. doi: 10.1016/j.vetmic.2014.01.023

Beutin, L., Hammerl, J. A., Strauch, E., Reetz, J., Dieckmann, R., Kelner-Burgos, Y., et al. (2012). Spread of a distinct Stx2-encoding phage prototype among 
Escherichia coli O104:H4 strains from outbreaks in Germany, Norway, and Georgia. J. Virol. 86, 10444-10455. doi: 10.1128/JVI.00986-12

Bibbal, D., Loukiadis, E., Kérourédan, M., Peytavin de Garam, C., Ferré, F., Cartier, P., et al. (2014). Intimin gene (eae) subtype-based real-time PCR strategy for specific detection of shiga toxin-producing Escherichia coli serotypes O157:H7, O26:H11, O103:H2, O111:H8, and O145:H28 in cattle feces. Appl. Environ. Microbiol. 80, 1177-1184. doi: 10.1128/AEM.03161-13

Breum, S. O., and Boel, J. (2010). Prevalence of Escherichia coli O157 and verocytotoxin producing E. coli(VTEC) on Danish beef carcasses. Int. J. Food Microbiol. 141, 90-96. doi: 10.1016/j.ijfoodmicro.2010.03.009

Brock, T. D. (1983). Membrane Filtration: A User's Guide and Reference Manual. Madison, WI: Science Technology Springer-Verlag.

Buchan, B. W., Olson, W. J., Pezewski, M., Marcon, M. J., Novicki, T., Uphoff, T. S., et al. (2013). Clinical evaluation of a real-time PCR assay for identification of Salmonella, Shigella, Campylobacter (Campylobacter jejuni and C. coli), and shiga toxin-producing Escherichia coli isolates in stool specimens. J. Clin. Microbiol. 51, 4001-4007. doi: 10.1128/JCM.02056-13

Bushman, F. (2002). Lateral DNA Transfer. New York, NY: Cold Spring Harbor Laboratory.

Dee, S. W., and Fogleman, J. C. (1992). Rates of inactivation of waterborne coliphages by monochloramine. Appl. Environ. Microbiol. 58, 3136-3141.

Díaz-Sánchez, S., Sánchez, S, Sánchez, M., Herrera-León, S., Hanning, I., and Vidal, D. (2012). Detection and characterization of Shiga toxin-producing Escherichia coli in game meat and ready-to-eat meat products. Int. J. Food Microbiol. 160 179-182. doi: 10.1016/j.ijfoodmicro.2012.09.016

Dumke, R., Schroter-Bobsin, U., Jacobs, E., and Roske, I. (2006). Detection of phages carrying the Shiga toxin 1 and 2 genes in waste water and river water samples. Lett. Appl. Microbiol. 42, 48-53. doi: 10.1111/j.1472765X.2005.01809.X

Durán, A. E., Muniesa, M., Méndez, X., Valero, F., Lucena, F., and Jofre, J. (2002). Removal and inactivation of indicator bacteriophages in fresh waters. J. Appl. Microbiol. 92, 338-347. doi: 10.1046/j.1365-2672.2002.01536.x

Environmental Protection Agency (EPA). (2000). Method 1602: Male-specific $(F+)$ and Somatic Coliphages in Water by Single Agar Layer (SAL) Procedure. Washington DC: Office of Water. United States Environmental Protection Agency.

Erickson, M. C., and Doyle, M. P. (2007). Food as a vehicle for transmission of Shiga toxin-producing Escherichia coli. J. Food Prot. 70, 2426-2449.

Feng, P., Weagant, S. D., and Jinneman, K. (2011). "Diarrheagenic Escherichia coli," in Inited States Food and Drug Administration. Bacteriological Analytical Manual. Available online at: http://www.fda.gov/Food/FoodScienceResearch/ LaboratoryMethods/ucm070080.htm

Fratamico, P. M., Bagi, L. K., Bush, E. J., and Solow, B. T. (2004). Prevalence and characterization of shiga toxin-producing Escherichia coli in swine feces recovered in the National Animal Health Monitoring System's Swine 2000 study. Appl. Environ. Microbiol. 70, 7173-7178. doi: 10.1128/AEM.70.12.7173-71 78.2004

Fremaux, B., Raynaud, S., Beutin, L., and Rozand, C.V. (2006). Dissemination and persistence of Shiga toxin-producing Escherichia coli (STEC) strains on French dairy ferms. Vet. Microbiol. 117, 180-191. doi: 10.1016/j.vetmic.2006.04.030

Garcia-Aljaro, C., Muniesa, M., Jofre, J., and Blanch, A. R. (2009). Genotypic and phenotypic diversity among induced, stx2-carrying bacteriophages from environmental Escherichia coli strains. Appl. Environ. Microbiol. 75, 329-336. doi: 10.1128/AEM.01367-08

Gould, L. H., Bopp, C., Strockbine, N., Atkinson, R., Baselski, V., Body, B., et al. (2009). Recommendations for diagnosis of shiga toxin-producing Escherichia coli infections by clinical laboratories. MMWR Recomm. Rep. 58, 1-14.

Grys, T. E., Sloan, L. M., Rosenblatt, J. E., and Patel, R. (2009). Rapid and sensitive detection of Shiga toxin-producing Escherichia coli from non-enriched stool specimens by real-time PCR in comparison to enzyme immunoassay and culture. J. Clin. Microbiol. 47, 2008-2012. doi: 10.1128/JCM.02013-08

Harris, S. M., Yue, W. F., Olsen, S. A., Hu, J., Means W. J., McCormick, R. J., et al. (2012). Salt at concentrations relevant to meat processing enhances Shiga toxin 2 production in Escherichia coli O157:H7. Int. J. Food Microbiol. 159, 186-192. doi: 10.1016/j.ijfoodmicro.2012.09.007

Hofer, E., Stephan, R., Reist, M., and Zweifel, C. (2012). Application of a real-time PCR-based system for monitoring of O26, O103, O111, O145 and O157 Shiga toxin-producing Escherichia coli in cattle at slaughter. Zoonoses Public Health 59, 408-415. doi: 10.1111/j.1863-2378.2012.01468.x
Hong, S., Oh, K. H., Cho, S. H., Kim, J. C., Park, M. S., Lim, H. S., et al. (2009). Asymptomatic healthy slaughterhouse workers in South Korea carrying Shiga toxin-producing Escherichia coli. FEMS Immunol. Med. Microbiol. 56, 41-47. doi: 10.1111/j.1574-695X.2009.00545.x

Huang, A., Friesen, J., and Brunton, J. L. (1987). Characterization of a bacteriophage that carries the genes for production of Shiga-like toxin 1 in Escherichia coli. J. Bacteriol. 169, 4308-4312.

Hussein, H. S., and Bollinger, L. M. (2008). Influence of selective media on successful detection of Shiga toxin-producing Escherichia coli in food, fecal, and environmental samples. Foodborne Pathog. Dis. 5, 227-244. doi: $10.1089 /$ fpd.2008.0081

Imamovic, L., Ballesté, E., Jofre, J., and Muniesa, M. (2010). Quantification of Shiga toxin-converting bacteriophages in wastewater and in fecal samples by real-time quantitative PCR. Appl. Environ. Microbiol. 76, 5693-5701. doi: 10.1128/AEM.00107-10

Imamovic, L., Jofre, J., Schmidt, H., Serra-Moreno, R., and Muniesa, M. (2009). Phage-mediated Shiga toxin 2 gene transfer in food and water. Appl. Environ. Microbiol. 75, 1764-1768. doi: 10.1128/AEM.02273-08

Imamovic, L., and Muniesa, M. (2011). Quantification and evaluation of infectivity of shiga toxin-encoding bacteriophages in beef and salad. Appl. Environ. Microbiol. 77, 3536-3540. doi: 10.1128/AEM.02703-10

Jofre, J. (2007). "Indicators of waterborne enteric viruses in human viruses in water," in Series Perspectives in Medical Virology, Vol. 17, ed A. Bosch (Amsterdam: Elsevier), 227-249. doi: 10.1016/S0168-7069(07)17011-7

Johannessen, G. S., James, C. E., Allison, H. E., Smith, D. L., Saunders, J. R., and McCarthy, A. J. (2005). Survival of a Shiga toxin-encoding bacteriophage in a compost model. FEMS Microbiol. Lett. 245, 369-375. doi: 10.1016/j.femsle.2005.03.031

Kagkli, D. M., Weber, T. P., Van den Bulcke, M., Folloni, S., Tozzoli, R., Morabito, S., et al. (2011). Application of the modular approach to an in-house validation study of real-time PCR methods for the detection and serogroup determination of verocytotoxigenic Escherichia coli. Appl. Environ. Microbiol. 77, 6954-6963. doi: 10.1128/AEM.05357-11

Karch, H., Denamur, E., Dobrindt, U., Finlay, B. B., Hengge, R., Johannes, L., et al. (2012). The enemy within us: lessons from the 2011 European Escherichia coli O104:H4 outbreak. EMBO Mol. Med. 4, 841-848. doi: 10.1002/emmm.201201662

Kimmitt, P. T., Harwood, C. R., and Barer, M. R. (2000). Toxin gene expression by Shiga toxin-producing Escherichia coli: the role of antibiotics and the bacterial SOS response. Emerg. Infect. Dis. 6, 458-465. doi: 10.3201/eid0605.000503

Köhler, B., Karch, H., and Schmidt, H. (2000). Antibacterials that are used as growth promoters in animal husbandry can affect the release of Shiga-toxin2-converting bacteriophages and Shiga toxin 2 from Escherichia coli strains. Microbiology 146, 1085-1090.

Langsrud, S., Heir, E., and Rode, T. M. (2013). Survival of Shiga toxin-producing Escherichia coli and Stx bacteriophages in moisture enhanced beef. Meat Sci. doi: 10.1016/j.meatsci.2013.09.022. [Epub ahead of print].

Lee, H. S., and Sobsey M. D. (2011). Survival of prototype strains of somatic coliphage families in environmental waters and when exposed to UV lowpressure monochromatic radiation or heat. Water Res. 45, 3723-3734. doi: 10.1016/j.watres.2011.04.024

Lin, L., Honh, W., Ji, X., Han, J., Huang, L., and Wei, Y. (2010). Isolation and characterization of an extremely long tail Thermus bacteriophage from Tegchong hot springs in China. J. Basic Microbiol. 50, 452-456. doi: 10.1002/jobm.201000116

Loukiadis, E., Nobe, R., Herold, S., Tramuta, C., Ogura, Y., Ooka, T., et al. (2008). Distribution, functional expression, and genetic organization of Cif, a phage-encoded type III-secreted effector from enteropathogenic and enterohemorrhagic Escherichia coli. J. Bacteriol. 190, 275-285. doi: 10.1128/JB.00844-07

Mann, B. A., and Slauch, J. M. (1997). Transduction of low copy numbers of plasmids by bacteriophages by bacteriophage $\mathrm{P} 22$. Genetics $146,447-456$.

Martinez-Castillo, A., Quirós, P., Navarro, F., Miró, E., and Muniesa, M. (2013). Shiga toxin 2-encoding bacteriophages in human fecal samples from healthy individuals. Appl. Environ. Microbiol. 79, 4862-4868. doi: 10.1128/AEM.01 158-13

Maurer, J. J., Schmidt, D., Petrosko, P., Sanchez, S., Bolton, L., and Lee, M. D. (1999). Development of primers to O-antigen biosynthesis genes for specific detection of Escherichia coli O157 by PCR. Appl. Environ. Microbiol. 65, 2954-2960. 
Mauro, S. A., and Koudelka, G. B. (2011). Shiga toxin: expression, distribution, and its role in the environment. Toxins 3, 608-625. doi: 10.3390/toxins3060608

Melton-Celsa, A., Mohawk, K., Teel, L., and O’Brien, A. (2012). Pathogenesis of Shiga-toxin producing Escherichia coli. Curr. Top Microbiol. Immunol. 357, 67-103. doi: 10.1007/82_2011_176

Meng, Q., Bai, X., Zhao, A., Lan, R., Du, H., Wang, T., et al. (2014). Characterization of Shiga toxin- producing Escherichia coli isolated from healthy pigs in China. BMC Microbiol. 14:5. doi: 10.1186/1471-2180-14-5

Mocé-Llivina, L., Jofre, J., and Muniesa, M. (2003). Comparison of polyvinylidene fluoride and polyether sulfone membranes in filtering viral suspensions. J. Virol. Methods. 109, 99-101. doi: 10.1016/S0166-0934(03)00046-6

Monaghan, A., Byrne, B., Fanning, S., Sweeney, T., McDowell, D., and Bolton, D. J. (2012). Serotypes and virulotypes of non-O157 shiga-toxin producing Escherichia coli (STEC) on bovine hides and carcasses. Food Microbiol. 32, 223-229. doi: 10.1016/j.fm.2012.06.002

Monday, S. R., Beisaw, A., and Feng, P. C. (2007). Identification of Shiga toxigenic Escherichia coli seropathotypes A and B by multiplex PCR. Mol. Cell Probes 21, 308-311. doi: 10.1016/j.mcp.2007.02.002

Muhldorfer, I., Hacker, J., Keusch, G. T., Acheson, D. W. K., Tschaepe, H., Kane, A. V., et al. (1996). Regulation of the Shiga-like toxin II operon in Escherichia coli. Infect. Immun. 64, 495-502.

Muniesa, M., Blanch, A. R., Lucena, F., and Jofre, J. (2005). Bacteriophages may bias outcome of bacterial enrichment cultures. Appl. Environ. Microbiol. 71, 4269-4275. doi: 10.1128/AEM.71.8.4269-4275.2005

Muniesa, M., Blanco, J. E., De Simón, M., Serra-Moreno, R., Blanch, A. R., and Jofre, J. (2004a). Diversity of stx2 converting bacteriophages induced from Shiga-toxin-producing Escherichia coli strains isolated from cattle. Microbiology 150, 2959-2971. doi: 10.1099/mic.0.27188-0

Muniesa, M., and Jofre, J. (1998). Abundance in sewage of bacteriophages that infect Escherichia coli $\mathrm{O} 157: \mathrm{H} 7$ and that carry the Shiga toxin 2 gene. Appl. Environ. Microbiol. 64, 2443-2448.

Muniesa, M., and Jofre, J. (2000). Occurrence of phages infecting Escherichia coli O157H7 carrying the stx 2 gene in sewage from different countries. FEMS Microbiol. Lett. 183, 197-200. doi: 10.1111/j.1574-6968.2000.tb08957.x

Muniesa, M., Lucena, F., and Jofre, J. (1999). Comparative survival of free shiga toxin 2-encoding phages and Escherichia coli strains outside the gut. Appl Environ. Microbiol. 65, 5615-5618.

Muniesa, M., Serra-Moreno, R., and Jofre, J. (2004b). Free Shiga toxin bacteriophages isolated from sewage showed diversity although the stx genes appeared conserved. Environ. Microbiol. 6, 716-725. doi: 10.1111/j.14622920.2004.00604.x

Neely, M. N., and Friedman, D. I. (1998). Functional and genetic analysis of regulatory regions of coliphage $\mathrm{H}-19 \mathrm{~B}$ : location of shiga-like toxin and lysis genes suggest a role for phage functions in toxin release. Mol. Microbiol. 28, 1255-1267. doi: 10.1046/j.1365-2958.1998.00890.x

Newland, J. W., Strockbine, N. A., Miller, S. F., O'Brien, A. D., and Holmes, R. K. (1985). Cloning of Shiga-like toxin structural genes from a toxin converting phage of Escherichia coli. Science 230, 179-181. doi: 10.1126/science. 2994228

O’Brien, A. D., Marques, L. R., Kerry, C. F., Newland, J. W., and Holmes, R. K. (1989). Shiga-like toxin converting phage of enterohemorrhagic Escherichia coli strain 933. Microb. Pathog. 6, 381-390. doi: 10.1016/0882-4010(89)90080-6

Ogunseitan, O. A., Sayler, G. S., and Miller, R. V. (1990). Dynamic interactions of Pseudomonas aeruginosa and bacteriophages in lake water. Microb. Ecol. 19, 171-185.

Pacheco, A. R., and Sperandio, V. (2009). Inter-kingdom signaling: chemical language between bacteria and host. Curr. Opin. Microbiol. 12, 192-198. doi: 10.1016/j.mib.2009.01.006

Papageorgiou, G. T., Mocé-Llivina, L., Christodoulou, C. G., Lucena, F., Akkelidou, D., Ioannou, E., et al. (2000). A simple methodological approach for counting and identifying culturable viruses adsorbed to cellulose nitrate membrane filters. Appl. Environ. Microbiol. 66, 194-198. doi: 10.1128/AEM.66.1.194198.2000

Paton, J. C., and Paton, A. W. (2003). "Methods for detection of STEC in humans: an overview," in Escherichia coli: Shiga Toxin Methods and Protocols. Methods in Molecular Medicine. Vol. 73, eds D. Philpott and F. Ebel (Totowa, NJ: Humana Press), 9-26.

Perelle, S., Dilasser, F., Grout, J., and Fach, P. (2004). Detection by $5^{\prime}$-nuclease PCR of Shiga-toxin producing Escherichia coli O26, O55, O91, O103, O111, O113,
O145 and O157:H7, associated with the world's most frequent clinical cases. Mol. Cell. Probe. 18, 185-192. doi: 10.1016/j.mcp.2003.12.004

Picozzi, C., Volponi, G., Vigentini, I., Grassi, S., and Foschino, R. (2012). Assessment of transduction of Escherichia coli Stx2-encoding phage in dairy process conditions. Int. J. Food Microbiol. 153, 388-394. doi: 10.1016/j.ijfoodmicro.2011.11.031

Pradel, N., Livrelli, V., De Champs, C., Palcoux, J. B., Reynaud, A., Scheutz, F., et al. (2000). Prevalence and characterization of Shiga toxin-producing Escherichia coli isolated from cattle, food, and children during a one-year prospective study in France. J. Clin. Microbiol. 38, 1023-1031.

Prigent, M., Leroy, M., Confalonieri, F., Dutertre, M., and DuBow, M. S. (2005). A diversity of bacteriophages forms and genomes can be isolated from the surface sands of Sahara Desert. Extremophiles 9, 289-296. doi: 10.1007/s00792-0050444-5

Rietra, P. J., Willshaw, G. A., Smith, H. R., Field, A. M., Scotland, S. M., and Rowe, B. (1989). Comparison of Vero-cytotoxin-encoding phages from Escherichia coli of human and bovine origin. J. Gen. Microbiol. 135, 2307-2318. doi: 10.1099/00221287-135-8-2307

Rode, T. M., Axelsson, L., Granum, P. E., Heir, E., Holck, A., and L'abée-Lund, T. M. (2011). High stability of Stx2 phage in food and under food-processing conditions. Appl. Environ. Microbiol. 77, 5336-5341. doi: 10.1128/AEM.00 180-11

Rogerie, F., Marecata, A., Gambadeb, S., Duponda, F., Beauboisb, P., and Langea, M. (2001). Characterization of Shiga toxin producing E. coli and O157 serotype E. coli isolated in France from healthy domestic cattle. Int. J. Food Microbiol. 63, 217-223. doi: 10.1016/S0168-1605(00)00422-0

Rooks, D. J., Libberton, B., Woodward, M. J., Allison, H. E., and McCarthy, A. J. (2012). Development and application of a method for the purification of free shigatoxigenic bacteriophage from environmental samples. J. Microbiol. Methods 91, 240-245. doi: 10.1016/j.mimet.2012.08.017

Rooks, D. J., Yan, Y., McDonald, J. E., Woodward, M. J., McCarthy, A. J., and Allison, H. E. (2010). Development and validation of a qPCR-based method for quantifying Shiga toxin-encoding and other lambdoid bacteriophages. Environ. Microbiol. 12, 1194-1204. doi: 10.1111/j.1462-2920.2010.02162.x

Saxena, A., Tripathi, B. P., Kumar, M., and Shahi, V. K. (2008). Membrane-based techniques for the separation and purification of proteins: an overview. Adv. Colloid Interface 145, 1-22. doi: 10.1016/j.cis.2008.07.004

Schmieger, H., and Schicklmaier, P. (1999). Transduction of multiple drug resistance of Salmonella enterica serovar Typhimurium DT104. FEMS Microbiol. Lett. 170, 251-256. doi: 10.1111/j.1574-6968.1999.tb13381.x

Stephan, R., Ragettli, S., and Untermann, F. (2000). Prevalence and characteristics of verotoxin-producing Escherichia coli (VTEC) in stool samples from asymptomatic human carriers working in the meat processing industry in Switzerland. J. Appl. Microbiol. 88, 335-341. doi: 10.1046/j.1365-2672.2000. 00965.x

Tanji, Y., Mizoguchi, K., Yoichi, M., Morita, M., Kijima, N., Kator, H., et al. (2003). Seasonal change and fate of coliphages infected to Escherichia coli O157:H7 in a waste water treatment plant. Water Res. 37, 1136-1142. doi: 10.1016/S00431354(02)00464-5

Tarr, P. I., Gordon, C. A., and Chandler, W. L. (2005). Shiga-toxin-producing Escherichia coli and haemolytic uraemic syndrome. Lancet 365, 1073-1086. doi: 10.1016/S0140-6736(05)71144-2

Thomason, L. C., Costantino, N., and Court, D. L. (2007). E. coli genome manipulation by $\mathrm{P} 1$ transduction. Curr. Protoc. Mol. Biol. Chapter 1:Unit 1.17. doi 10.1002/0471142727.mb0117s79

Toshima, H., Yoshimura, A., Arikawa, K., Hidaka, A., Ogasawara, J., Hase, A., et al. (2007). Enhancement of Shiga toxin production in enterohemorrhagic Escherichia coli serotype O157:H7 by DNase colicins. Appl. Environ. Microbiol. 73, 7582-7588. doi: 10.1128/AEM.01326-07

Trevisani, M., Mancusi, R., Delle, Donne, G., Bacci, C., Bassi, L., et al. (2014). Detection of Shiga toxin (Stx)-producing Escherichia coli (STEC) in bovine dairy herds in Northern Italy. Int. J. Food. Microbiol. doi: 10.1016/j.ijfoodmicro. 2013.12.033. [Epub ahead of print].

Tyler, J. S., Miller, M. J., and Friedman, D. I. (2004). The operator and early promoter region of the Shiga toxin type 2-ecoding bacteriophage $933 \mathrm{~W}$ and control of toxin expression. J. Bacteriol. 186, 7670-7679. doi: 10.1128/JB.186.22.76707679.2004

Underwood, A. P., Dallman, T., Thomson, N. R., Williams, M., Harker, K., Perry, N., et al. (2013). Public health value of next-generation DNA sequencing of 
enterohemorrhagic Escherichia coli isolates from an outbreak. J. Clin. Microbiol. 51, 232-237. doi: 10.1128/JCM.01696-12

Urdahl, A. M., Solheim, H. T., Vold, L., Hasseltvedt, V., and Wasteson, Y. (2012). Shiga toxin-encoding genes (stx genes) in human fecal samples. APMIS 121, 202-210. doi: 10.1111/j.1600-0463.2012.02957.x

USDA FSIS. (2012). Risk Profile for Pathogenic Non-O157 Shiga ToxinProducing Escherichia coli (non-O157 STEC). Available online at: http://www.fsis.usda.gov/PDF/Non_O157_STEC_Risk_Profile_May2012.pdf

Vallières, E., Saint-Jean, M., and Rallu, F. (2013). Comparison of three different methods for detection of Shiga toxin-producing Escherichia coli in a tertiary pediatric care center. J. Clin. Microbiol. 51, 481-486. doi: 10.1128/JCM.02219-12

Van Reis, R., and Zydney, A. (2001). Membrane separations in biotechnology. Curr. Opin. Biotechnol. 12, 208-211. doi: 10.1016/S0958-1669(00)00201-9

Wagner, P. L., Neely, M. N., Zhang, X., Acheson, D. W., Waldor, M. K., and Friedman, D. I. (2001). Role for a phage promoter in Shiga toxin 2 expression from a pathogenic Escherichia coli strain. J. Bacteriol. 183, 2081-2085. doi: 10.1128/JB.183.6.2081-2085.2001

Wester, A. L., Brandal, L. T., and Dahle, U. R. (2013). Extraintestinal pathogenic Escherichia coli carrying the Shiga Toxin gene stx. 2 . J. Clin. Microbiol. 51, 4279-4280. doi: 10.1128/JCM.01349-13

Wong, C. S., Jelacic, S., Habeeb, R. L., Watkins, S. L., and Tarr, P. I. (2000). The risk of the hemolytic-uremic syndrome after antibiotic treatment of Escherichia coli O157:H7 infections. N. Engl. J. Med. 342, 1930-1936. doi: 10.1056/NEJM200006293422601

Yamamoto, T., Kojio, S., Taneike, I., Nakagawa, S., Iwakura, N., and WakisakaSaito, N. (2003). ${ }^{60}$ Co irradiation of Shiga toxin (Stx)-producing Escherichia coli induces Stx phage. FEMS Microbiol. Lett. 222, 115-121. doi: 10.1016/S03781097(03)00259-3
Yan, Y., Shi, Y., Cao, D., Meng, X., Xia, L., and Sun, J. (2011). Prevalence of Stx phages in environments of a pig farm and lysogenic infection of the field $E$. coli O157 isolates with a recombinant converting Phage. Curr. Microbiol. 62, 458-464. doi: 10.1007/s00284-010-9729-8

Yue, W. F., Du, M., and Zhu, M. J. (2012). High temperature in combination with UV irradiation enhances horizontal transfer of $s_{2} x_{2}$ gene from E. coli O157:H7 to non-pathogenic E. coli. PLoS ONE 7:e31308. doi: 10.1371/journal.pone. 0031308

Conflict of Interest Statement: The authors declare that the research was conducted in the absence of any commercial or financial relationships that could be construed as a potential conflict of interest.

Received: 06 March 2014; paper pending published: 22 March 2014; accepted: 27 March 2014; published online: 16 April 2014.

Citation: Martinez-Castillo A and Muniesa M (2014) Implications of free Shiga toxin-converting bacteriophages occurring outside bacteria for the evolution and the detection of Shiga toxin-producing Escherichia coli. Front. Cell. Infect. Microbiol. 4:46. doi: 10.3389/fcimb.2014.00046

This article was submitted to the journal Frontiers in Cellular and Infection Microbiology.

Copyright (c) 2014 Martínez-Castillo and Muniesa. This is an open-access article distributed under the terms of the Creative Commons Attribution License (CC BY). The use, distribution or reproduction in other forums is permitted, provided the original author(s) or licensor are credited and that the original publication in this journal is cited, in accordance with accepted academic practice. No use, distribution or reproduction is permitted which does not comply with these terms. 